\title{
Immunosuppressive effect of medicinal plants of Kolli hills on mitogen-stimulated proliferation of the human peripheral blood mononuclear cells in vitro
}

\author{
S. Arokiyaraj, K. Perinbam, P. Agastian*, K. Balaraju*
}

PG and Research, Sathyabama University, Chennai - 600 119;

*Department of Plant Biology and Biotechnology, School of Life Sciences, Loyola College, Chennai - 600 034, India

Received: 07.07.2007

Revised: 10.08 .2007

Accepted: 30.08 .2007

Correspondence to: K. Perinbam

E-mail: sistperinbam@yahoo.com

\begin{abstract}
Four medicinal plant species were collected from the Kolli hills of Tamil Nadu and were screened for their immunosuppressive effect. The plants were shade dried and extracted with methanol. The crude methanol extracts were tested for inhibition of lymphocyte proliferation via lymphocyte proliferation assay by ${ }^{3}$ thymidine uptake. The test plants were Justicia gendarussa, Plumbago indica, Aloe vera, and Aegle marmelos. Among the plants tested J. gendarussa $(100 \mu \mathrm{g} / \mathrm{ml})$ showed the highest lymphocyte inhibition $(84 \%)$. Sequential extraction of $J$. gendarussa in various solvents (n-hexane, benzene, ethyl acetate, chloroform, acetone, ethanol, and water) confirmed that all of the above extracts at $50 \mu \mathrm{g} / \mathrm{ml}$, aqueous extract inhibited lymphocyte proliferation. Further, 17 high performance liquid chromatography fractions w ere collected for the aqueous extract and fraction no. 15 showed maximum inhibition of lymphocyte proliferation. The present study indicates that these extracts should be investigated further for the possible presence of immunosuppressive components.
\end{abstract}

KEY WORDS: Cytotoxic, immune system, mitogen, secondary metabolites
Modulation of immune response, as a possible therapeutic measure, by using medicinal plant products has become a subject of scientific investigation. Indian medicinal plants are commonly used for the treatment of various ailments and are considered, by many, to have advantages over the conventionally used drugs, which are expensive and known to have harmful side effects. ${ }^{[1]}$ Our immune system plays a vital role in protecting us from various infections. Its integrity and efficiency is important during the treatment of many diseases. ${ }^{[2]}$ Besides primary metabolites with immunomodualtory activity, several plant have secondary metabolites that have been found to interfere with different immune system functions, including the activation of cell-mediated immunity. ${ }^{[3,4]}$ Several studies have previously demonstrated the immunomodulating effects of medicinal plants on lymphocyte proliferation in the presence of mitogens, allogenic cells, and specific antigens. ${ }^{[5-7]}$ Knowing the potential of plant extracts as immunomodulators, the medicinal plants of the Kolli hills of Tamil Nadu were selected for this study. Although the local traditional healers have ethnomedical knowledge of the value of these plants, there have been no biological studies on the immunomodulatory activity of these plants. The present study was undertaken to test the extracts of four different medicinal plants for their immunomodulatory property on mitogen-induced lymphocyte proliferation in vitro.

\section{Material and Methods}

\section{Local traditional healers}

Ten local traditional healers who had practical experience with medicinal plants were interviewed in Kolli hills, Tamil Nadu, India, in the month of October 2006. They were interviewed separately and asked to collect the plants that they traditionally used for treating ailments such as rheumatism, cough, inflammation, diabetes, ulcers, and diarrhea. Of the collected plants, four were selected by the interviewer for the study. These plants were taxonomically identified and deposited in the department herbarium. The voucher specimens in duplicate were deposited in the department herbarium, Loyola College, Chennai (India).

Preparation of crude extracts

Fresh plant materials were washed under running water and shade dried. The parts were coarsely powdered and extracted with methanol after $48 \mathrm{~h}$. The solvent was removed by rotary evaporation under reduced pressure at $<45^{\circ} \mathrm{C}$ temperature. The resulting crude extracts were stored at $4^{\circ} \mathrm{C}$ until use. Subsequent extraction was carried out in a soxhlet extraction unit (Borosil, Mumbai) using n-hexane, ethyl acetate, chloroform, ethanol 96\%, benzene, acetone, and water. Organic solvents were removed under reduced pressure. Water was removed by freeze drying. The resulting extracts were stored in vials and assayed. 
High performance liquid chromatography (HPLC) analysis

A Shimadzu model LC-64 liquid chromatograph with C18 reversed-phase column was used to separate the major components of the aqueous extracts. After the column was washed to achieve the baseline, the gradient parameters were set and the run was started by injecting $250 \mu \mathrm{l}$ of the extract. A flow rate of $1.5 \mathrm{ml} / \mathrm{min}$ was employed. Peaks were detected by monitoring their absorbance at $405 \mathrm{~nm}$ and 280 $\mathrm{nm}$. The chromatogram was recorded on a Shimadzu-C-R 3 A chromatopac recording integrator. Chromatographic patterns were plotted for the extracts. Fractions were collected in a collector, evaporated in a rotary vacuum pump, and lyophilized.

\section{Cell culture}

Vero cells (African green monkey kidney cell) were obtained from the National Centre for Cell Science, Pune, India. Vero cells were grown in EMEM (Eagle's minimum essential medium) supplemented with Earle's salts and 10\% heat-inactivated NBCS (newborn calf serum), $100 \mathrm{IU} / \mathrm{ml}$ penicillin, $100 \mu \mathrm{g} /$ $\mathrm{ml}$ streptomycin, and $50 \mu \mathrm{g} / \mathrm{ml}$ gentamycin. The cells were maintained at $37^{\circ} \mathrm{C}$ in a humidified atmosphere with $5 \% \mathrm{CO}_{2}$ and were subcultured twice a week.

\section{Cytotoxicity assay ${ }^{[8]}$}

Each extract (crude methanol extract; the six different solvents such as n-hexane, benzene, ethyl acetate, chloroform, acetone, ethanol, and aqueous residues; and the 17 HPLC fractions) was dissolved separately in $1 \mathrm{ml}$ of $20 \%$ DMSO (dimethyl sulphoxide), filter sterilized, and then further diluted to attain concentrations of $2 \mathrm{mg} / \mathrm{ml}, 1 \mathrm{mg} / \mathrm{ml}, 0.5 \mathrm{mg} / \mathrm{ml}$, $0.25 \mathrm{mg} / \mathrm{ml}, 0.125 \mathrm{mg} / \mathrm{ml}$, and $0.062 \mathrm{mg} / \mathrm{ml}$. Cell suspension $(100 \mu \mathrm{l})$ containing $5 \times 10^{6}$ cells was seeded onto a 96-well microtiter plate. After $24 \mathrm{~h}$ of seeding, $100 \mu \mathrm{l}$ of the different concentrations of the extracts $(2 \mathrm{mg} / \mathrm{ml}, 1 \mathrm{mg} / \mathrm{ml}, 0.5 \mathrm{mg} / \mathrm{ml}$, $0.25 \mathrm{mg} / \mathrm{ml}, 0.125 \mathrm{mg} / \mathrm{ml}$, and $0.062 \mathrm{mg} / \mathrm{ml}$.) were added. Control consisted of cells without extract and with DMSO. The microtiter plates were incubated at $37^{\circ} \mathrm{C}$ in a humidified incubator with $5 \% \mathrm{CO}_{2}$ for period of $72 \mathrm{~h}$. The morphology of the cells was inspected daily and observed for microscopically detectable alterations.

\section{Isolation of peripheral blood mononuclear cells (PBMC)}

PBMC were obtained from healthy adult volunteers by centrifugation of heparinized venous blood over Ficoll/Hypaque solution (Histopaque, Sigma, St. Louis MO). Mononuclear cells were collected in the interphase and washed three times in RPMI-1640. Their viability was determined by trypan blue exclusion test. ${ }^{[9]}$ Cell suspensions were adjusted to $5 \times 10^{6}$ cell/ml and suspended in RPMI-1640 supplemented with $10 \%$ FCS.

\section{Lymphocyte proliferation assay by ${ }^{3} \mathrm{H}$ thymidine uptake}

The in vitro cellular proliferation was performed as previously described by Lie-Chwen Lin. ${ }^{[10]}$ The cell suspension $(100 \mu \mathrm{l})$ was seeded in each well of a 96-well flat-bottomed microtiter plate (Nunc 167008, Nuncton, Roskilde, Denmark). The cells were incubated for $24 \mathrm{~h}$. After incubation, $100 \mu \mathrm{l}$ of the extracts at different concentrations $(50,100,150 \mu \mathrm{g} / \mathrm{ml})$ were added. The cultures were stimulated with $20 \mu \mathrm{g} / \mathrm{ml}$ of PHA (Gibco BRC, Gaithersberg, MD). Controls consisted of PBMC with PHA (100\% stimulation activity), PBMC with RPMI (0\% activity), and sample with methanol ( $0 \%$ activity) as background sample. The plates were incubated in 5\% $\mathrm{CO}_{2}$ air humidified atmosphere at $37^{\circ} \mathrm{C}$ for $72 \mathrm{~h}$. Lymphocyte proliferation was estimated by adding ${ }^{3} \mathrm{H}$-thymidine ( $50 \mathrm{ci} / \mathrm{mmol}, 1 \mu \mathrm{ci} /$ well; Amershan USA). After $16 \mathrm{~h}$ of incubation, the cells were harvested on glass fiber filters. Radioactivity in the incorporated cells was measured by using a liquid scintillation counter (Packard TRI CARB 2100 TR USA).

Percentage of inhibition of lymphocyte proliferation for each extract was calculated by the following equation: ${ }^{10]}$

$$
\text { CPM (PHA) + CPM (extract treated) }
$$

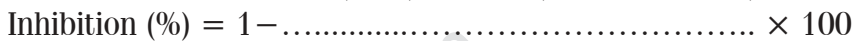

$$
\text { CPM (PHA) }
$$

\section{Statistical analysis}

Each experiment with PBMC was run in triplicate. Significance was calculated by Student's t test, through the ANOVA model. $\mathrm{P}<0.05$ was taken to indicate statistical significance. Results are reported as mean \pm S.D

\section{Results}

\section{Cytotoxicity assay}

None of the tested extracts (crude methanol extract; six different solvents such as n-hexane, benzene, ethyl acetate, chloroform, acetone, ethanol and aqueous residues; and the 17 HPLC fractions) of the four different medicinal plants showed any signs of cytotoxicity on the Vero cell line, even at the highest concentration of $2 \mathrm{mg} / \mathrm{ml}$, i.e., there was no loss of monolayer, granulation, or vacuolization in the cytoplasm [Figures 1 and 2].

\section{Lymphocyte proliferation assay by ${ }^{3} \mathrm{H}$ thymidine uptake}

Inhibition of lymphocyte proliferation: The methanol extract of the four medicinal plants (belonging to different families) used in the traditional system of medicine were tested for their ability to inhibit PBMC proliferation at a concentration between 50-150 $\mu \mathrm{g} / \mathrm{ml}$. After stimulation with PHA and incubation for $72 \mathrm{~h}$, all the four species inhibited PBMC proliferation, as measured by ${ }^{3} \mathrm{H}$-thymidine incorporation by DNA from the cells. Extract of J. gendarussa showed the maximum inhibitory activity, when compared to P. indica, Aloe vera and. Aegle marmelos, at a concentration of $100 \mu \mathrm{g} / \mathrm{ml}$ [Table 1].

Sequential extraction of $\mathrm{J}$. gendarussa showed more inhibitory effect on lymphocyte proliferation in aqueous, chloroform, and ethanol than in n-hexane, ethyl acetate, and benzene at a concentration of $50 \mu \mathrm{g} / \mathrm{ml}$ [Table 2].

\section{HPLC analysis}

Aqueous extract of $\mathrm{J}$. gendarussa showed the maximum inhibitory activity on lymphocyte proliferation; HPLC fractionation of this extract was carried out. 17 HPLC fractions were collected and tested for inhibition of lymphocyte proliferation. Out of 17 fractions tested, fraction no. 15 showed the maximum inhibition of $88 \%$ at a concentration of $10 \mu \mathrm{g} / \mathrm{ml}$ [Table 3].

\section{Discussion}

On comparison of the cell proliferation in nontreated and extract-treated cultures, the methanol extracts of $\mathrm{J}$. gendarussa, P. indica, Aloe vera, and A. marmelos showed the ability to cause 
Figure 1: Vero cell monolayer

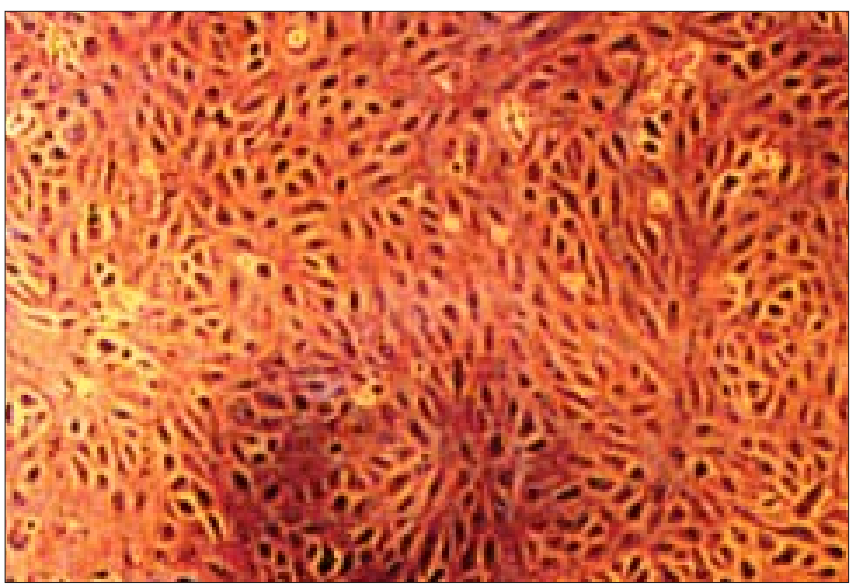

Figure 2: Vero cell treated with plant extract

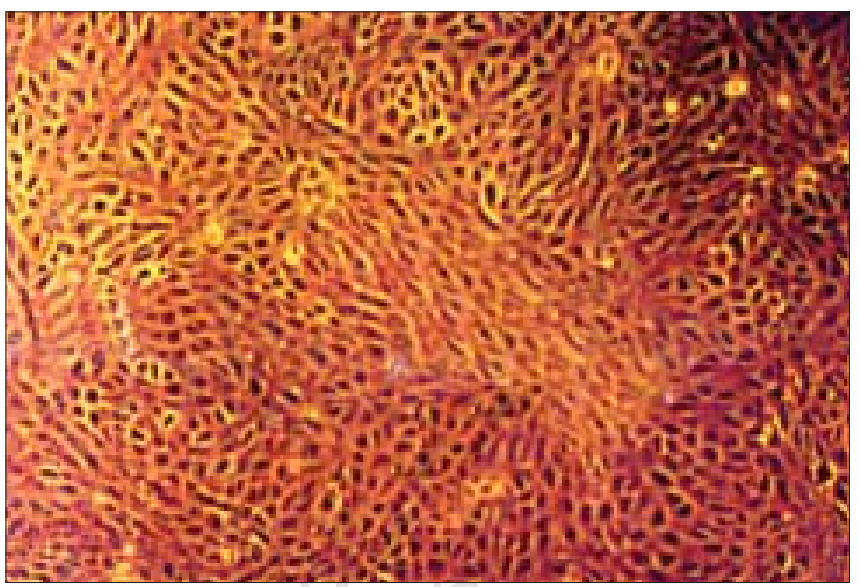

Table 1

Methanol extract of medicinal plants of Kolli hills

\begin{tabular}{lcccc}
\hline Botanical name & Part used & \% Inhibition $\mathbf{( 5 0} \boldsymbol{\mu g} / \mathbf{m l})$ & \% Inhibition (100 $\boldsymbol{\mu g} / \mathbf{m l})$ & $\%$ Inhibition (150 $\boldsymbol{\mu g} / \mathbf{m l})$ \\
\hline Justicia gendarussa & Leaf & $64 \pm 4$ & $84 \pm 3$ & $81 \pm 6$ \\
Plumbago indica & Root & $60 \pm 0$ & $80 \pm 2$ & $80 \pm 1$ \\
Aloe vera & Leaf & $61 \pm 6$ & $79 \pm 1$ & $78 \pm 2$ \\
Aegle marmelos & Leaf & $59 \pm 2$ & $77 \pm 2$ & $76 \pm 3$ \\
\hline
\end{tabular}

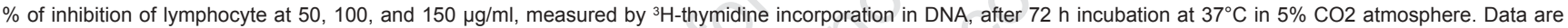
reported as the mean \pm S.D in triplicates. $P<0.01$ when compared to control (Student's $t$ test)

\section{Table 2}

Sequential extraction of Justicia gendarussa

\begin{tabular}{lccc}
\hline Solvent & $\begin{array}{c}\text { \% Inhibition } \\
(\mathbf{2 5} \boldsymbol{\mu g} / \mathbf{m l})\end{array}$ & $\begin{array}{c}\text { \% Inhibition } \\
(\mathbf{5 0} \boldsymbol{\mu g} / \mathbf{m l})\end{array}$ & $\begin{array}{c}\text { \% Inhibition } \\
(\mathbf{1 0 0} \boldsymbol{\mu g} / \mathbf{m l})\end{array}$ \\
\hline n-hexane & $60 \pm 2.0$ & $73 \pm 3.6$ & $65 \pm 4.0$ \\
Benzene & $50 \pm 5.0$ & $61 \pm 2.5$ & $50 \pm 1.5$ \\
Ethyl acetate & $52 \pm 3.5$ & $66 \pm 2.6$ & $60 \pm 6.0$ \\
Chloroform & $64 \pm 3.6$ & $84 \pm 2.3$ & $70 \pm 3.0$ \\
Acetone & $61 \pm 1.7$ & $76 \pm 1.5$ & $65 \pm 1.5$ \\
Ethanol & $61 \pm 2.0$ & $81 \pm 2.5$ & $77 \pm 5.3$ \\
Aqueous & $65 \pm 5.1$ & $90 \pm 2.6$ & $80 \pm 1.0$ \\
\hline
\end{tabular}

$\%$ of inhibition of lymphocyte at 25,50 , and $100 \mu \mathrm{g} / \mathrm{ml}$, measured by ${ }^{3} \mathrm{H}$-thymidine incorporation in DNA, after $72 \mathrm{~h}$ incubation in $37^{\circ} \mathrm{C}$ at $5 \% \mathrm{CO} 2$ atmosphere. Data are reported as the mean \pm S.D in triplicates. $P<0.01$ when compared to control (Student's $\mathrm{t}$ test)

significant decrease in mitogen (PHA)-induced lymphocyte proliferation at a concentration of $100 \mu \mathrm{g} / \mathrm{ml}$, suggesting that they affected the T-cell proliferation in a dose-dependent manner. The results from this preliminary investigation provide evidence of the importance of ethnopharmacology as a guide to the screening of biologically active plant materials. ${ }^{[11]} \mathrm{J}$. gendarussa, as a methanol extract, showed the maximum inhibition of $85 \%$. Similarly, crude methanolic extract obtained from leaves of Meliacea were capable of inhibiting the in vitro proliferation of lymphocytes and in inhibiting several immune responses in which these cells are involved. ${ }^{[2]}$ Rayward et al. ${ }^{[13]}$
Table 3

High performance liquid chromatography fractions of aqueous extract of Justicia gendarussa on human lymphocyte proliferation in response to PHA

\begin{tabular}{lccc}
\hline Fractions & $\begin{array}{c}\text { \% Inhibition } \\
(\mathbf{5} \boldsymbol{\mu g} / \mathbf{m} \mathbf{)})\end{array}$ & $\begin{array}{c}\text { \% Inhibition } \\
(\mathbf{1 0} \boldsymbol{\mu g} / \mathbf{m l})\end{array}$ & $\begin{array}{c}\text { \% Inhibition } \\
(\mathbf{1 5} \boldsymbol{\mu g} / \mathbf{m l})\end{array}$ \\
\hline 1 & $50 \pm 2.0$ & $69 \pm 1.5$ & $65 \pm 5.0$ \\
2 & $56 \pm 1.0$ & $74 \pm 2.0$ & $70 \pm 1.5$ \\
3 & $46 \pm 0.0$ & $52 \pm 1.0$ & $49 \pm 1.0$ \\
4 & $58 \pm 1.5$ & $81 \pm 1.5$ & $76 \pm 1.0$ \\
5 & $48 \pm 2.0$ & $66 \pm 2.5$ & $59 \pm 1.5$ \\
6 & $59 \pm 1.0$ & $80 \pm 1.0$ & $71 \pm 0.5$ \\
7 & $58 \pm 1.0$ & $81 \pm 0.5$ & $70 \pm 0.5$ \\
8 & $54 \pm 2.0$ & $71 \pm 0.5$ & $67 \pm 2.0$ \\
9 & $47 \pm 1.0$ & $58 \pm 0.5$ & $51 \pm 1.5$ \\
10 & $61 \pm 1.5$ & $83 \pm 0.5$ & $77 \pm 1.5$ \\
11 & $58 \pm 2.5$ & $65 \pm 1.1$ & $60 \pm 3.0$ \\
12 & $54 \pm 3.0$ & $70 \pm 1.0$ & $67 \pm 2.5$ \\
13 & $57 \pm 1.5$ & $65 \pm 0.5$ & $61 \pm 0.5$ \\
14 & $61 \pm 2.0$ & $85 \pm 1.0$ & $77 \pm 2.5$ \\
15 & $62 \pm 3.0$ & $88 \pm 0.5$ & $81 \pm 2.0$ \\
16 & $43 \pm 1.5$ & $55 \pm 0.5$ & $49 \pm 0.0$ \\
17 & $41 \pm 2.0$ & $59 \pm 0.5$ & $51 \pm 2.5$ \\
\hline
\end{tabular}

Effect of HPLC fractions of aqueous extract of Justicia gendarussa (1-17) on lymphocyte proliferation. \% of inhibition of lymphocyte at 5,10 , and $15 \mu \mathrm{g} / \mathrm{ml}$, measured by ${ }^{3} \mathrm{H}$-thymidine incorporation in DNA, after $72 \mathrm{~h}$ incubation at $37^{\circ} \mathrm{C}$ in $5 \%$ CO2 atmosphere. Data are reported as the mean \pm S.D in triplicates. $P<0.01$ when compared to control (Student's t test) 
showed that the inhibitory effect of the alcoholic extract of the fern Polypodium leucotomos in his assay was related to a direct effect on T-lymphocytes and/or macrophages. Similarly, water and ethanol extracts of Cypreus rotundus and Eclipta alba strongly decreased PBMC proliferation in a dose-dependent manner. ${ }^{[14]}$ Before performing the assay, trypan blue viability test was performed to check for $100 \%$ viability of PBMC. After 24,48 , and $72 \mathrm{~h}$, all the extract-treated cells were checked for viability and in each case their viability was $>90 \%$. Similarly, in the present study, we have observed that the inhibitory effects could not be considered as the toxic effect of the plants.

The present study indicated that proliferation of PHA-activated mononuclear cells was significantly inhibited by $100 \mu \mathrm{g} / \mathrm{ml}$ and 50 $\mu \mathrm{g} / \mathrm{ml}$; in comparison, concentrated lime juice extract inhibited PHA-stimulated MNC at 250 and $500 \mu \mathrm{g} / \mathrm{ml}^{.15]}$

It is also important to note that a beneficial effect was observed; the traditional aqueous extract of $\mathrm{J}$. gendarussa showed a strong immunosuppressive effect on mitogenstimulated lymphocytes at a low concentration of $50 \mu \mathrm{g} / \mathrm{ml}$.

$\mathrm{J}$. gendarussa is common throughout India in waste places, hedges, and village shrubberies. It is an effective medicinal plant for chronic rheumatism, cephalalgia, cough, and bronchitis. The chemical constituents in the plant's leaves includes 0-disubstiuted aromatic amines, 2-amino benzyl alcohol, 2(2'-amino benzyl amino) benzyl alchol, and their respective 0 -methyl ethers, friedelin, lupeol, and $\beta$-sitosterol. ${ }^{[16]}$

This study revealed the inhibitory activity of $\mathrm{J}$. gendarussa extract on nonspecific cellular immune response. Although the exact mechanism of this effect is not known, it may be mediated by the interaction between the active components of the extracts and cell-surface molecules or growth factors involving mitogen activation, and it is possible that identification and elucidation of the active constituents in this plant may provide useful leads to the development of new and effective immunosuppressant drugs.

\section{Acknowledgment}

We sincerely express our gratitude to Mr. Jeppiar, Chairman, Sathyabama University, for his guidance and financial support during the course of our research work. We also thank the department of Microbiology, IBMS, University of Madras, Taramani, Chennai, for their wonderful technical support.

\section{References}

1. Khare $\mathrm{CP}$, editor. In: Encyclopedia of Indian medicinal plant-Rational Western therapy, Ayurvedic and other traditional usage, Botany $2^{\text {nd }}$ ed. Springer Verlag: New Delhi; 2004.

2. Ishizuka M, Kawatsu M, Yamashita T, Ueno M, Takeuchi T. Low molecular weight immunomodulators produced by microorganisms. Int J Immunopharmacol 1995;17:133-9.

3. Wagner $\mathrm{H}$. Leading structures of plant origin for drug development. J Ethnopharmacol 1993;38:105-12.

4. Wong CK, Leung KN, Fung KP, Choy YM. Immunomodulatory and anti-tumor polysaccharides from medicinal plants. J Int Med Res 1994;22:299-312.

5. Lamm DL, Riggs DR. The potential application of Allium sativum (garlic) for the treatment of bladder cancer. Urol Clin North Am 2000;27:157-62.

6. Summerfield A, Saalmuller A. Interleukin-2 dependent selective activation of porcine gamma delta $T$ lymphocyte by an extract from the leaves of Acanthospermum hispidum. Int J Immunopharmacol 1998;20:85-98.

7. Peacock JS, Colsky AS, Pinto VB. Lectins and antibodies as tools for studying cellular interactions. J Immunol Methods 1990;126:147-57.

8. Elanchezhiyan M, Rajarajan S, Rajendran P, Subramanian, Thyagarajan SP. Antiviral properties of the seed extract of an Indian medicinal plant, Pongamia pinnata, Linn, against Herpes simplex viruses:in-vitro studies on Vero cells. J Med Microbiol 1993;38:262-4.

9. Moldeus P, Hogberg J, Orrhenius S, Fleischer S, Packer L. Methods in enzymology. Vol.52, Academic Press: New York; 1978. p. 60-71.

10. Lin LC, Kuo YC, Chou CJ. Immunomodulatory principles of Dichrocephala bicolor. J Nat Prod 1999;62:405-8.

11. Farnsworth NR, Kaos CJ. An approach utilizing information from traditional medicine to identify tumor-inhibiting plants. J Ethnopharmacol 1981;3:85-99.

12. Benencia F, Courrèges MC, Coulombié FC. Immunomodulatory activities of Trichila glabra leaf aqueous extracts. J Ethnopharmacol 2000;69:199-205.

13. Rayward J, Villarrubia VG, Guillen C, Prieto A, Rodriguez-Zapata M, Sada G, et al. An extract of the fern Polypodium leucotomos inhibits human peripheral blood mononuclear cells proliferation in vitro. Int J Immunopharmacol 1997;19:9-14.

14. Punturee K, Wild CP, Kasinrerk W, Vinitketkumnuen U. Immunomodulatory effects of Thai Medicinal plants on the mitogen stimulated proliferation of human peripheral blood mononuclear cells in vitro. Chiang Mai Med Bull 2005;44:112.

15. Gharagozloo M, Ghaderi A. Immunomodulatory effect of concentrated lime juice extract on activated human mononuclear cells. J Ethnopharmacol 2001;77:8590.

16. The Wealth of India: A dictionary of Indian raw materials and industrial products. CSIR: New Delhi; 1959. Vol:5, p. 312. 